\title{
Personalized identification of tumor-associated immunogenic neoepitopes in hepatocellular carcinoma in complete remission after sorafenib treatment
}

\author{
Sindy Vrecko ${ }^{1}$, David Guenat ${ }^{1,2,3,4}$, Patricia Mercier-Letondal ${ }^{1}$, Hugues Faucheu ${ }^{1,3}$, \\ Magalie Dosset ${ }^{1,2}$, Bernard Royer ${ }^{1,5}$, Jeanne Galaine ${ }^{1}$, Romain Boidot ${ }^{6}$, Stefano \\ Kim $^{7}$, Marine Jary ${ }^{1,7}$, Olivier Adotévi ${ }^{1,7}$, Christophe Borg ${ }^{1,7}$ and Yann Godet ${ }^{1}$ \\ ${ }^{1}$ University Bourgogne Franche-Comté, INSERM, EFS BFC, UMR1098, Interactions Hôte-Greffon-Tumeur/Ingénierie Cellulaire \\ et Génique, Besançon F-25000, France \\ ${ }^{2}$ University Bourgogne Franche-Comté, LabEx LipSTIC ANR-11-LABX-0021, Besançon F-25000, France \\ ${ }^{3}$ University Hospital of Besançon, Department of Molecular and Cell Biology, Besançon F-25000, France \\ ${ }^{4}$ Stanford Cancer Institute, Department of Medicine, Division of Oncology, Stanford University, Stanford, CA 94305, USA \\ ${ }^{5}$ University Hospital of Besançon, Department of Pharmacology, Besançon F-25000, France \\ ${ }^{6}$ Centre Georges-François Leclerc, Platform of Transfer in Cancer Biology, Department of Biology and Pathology of Tumours, \\ Centre de Recherche INSERM LNC-UMR123, Dijon F-21000, France \\ ${ }^{7}$ University Hospital of Besançon, Department of Medical Oncology, Besançon F-25000, France \\ Correspondence to: Yann Godet, email: yann.godet@univ-fcomte.fr \\ Keywords: neoepitopes; mutations; hepatocellular carcinoma; CD4 T cells; sorafenib \\ Abbreviations: HCC: Hepatocellular Carcinoma; MoDC: Monocyte derived Dendritic Cells; PBMC: Peripheral Mononuclear Cells; \\ SNVs: Single-Nucleotide Variants; WES: Whole Exome Sequencing \\ Received: June 23, $2018 \quad$ Accepted: October 08, $2018 \quad$ Published: October 23, 2018 \\ Copyright: Vrecko et al. This is an open-access article distributed under the terms of the Creative Commons Attribution License \\ 3.0 (CC BY 3.0), which permits unrestricted use, distribution, and reproduction in any medium, provided the original author and \\ source are credited.
}

\section{ABSTRACT}

Sorafenib, a multi-targeted kinase inhibitor, is the current standard systemic treatment for advanced hepatocellular carcinoma. Sorafenib has anti-angiogenic and antiproliferative properties and is also known to favor anti-tumor $\mathrm{T}$ cell responses by reducing the population of immunosuppressive cells such as Treg and MDSC. Anti-tumor immune responses, especially mediated by CD4+ T-cells, are critical for tumor cells eradication and therapies modulating those responses are appealing in a growing number of cancers.

Here, we report and investigate the case of a patient diagnosed with an advanced HCC treated by sorafenib who experienced a complete histological response. We aimed to identify immunogenic peptides derived from tumor mutated proteins that stimulated CD4+ $T$ cells responses thus favoring the exceptional recovery process of this patient.

Tumor neoantigens were identified using whole exome sequencing of normal and tumor tissue and peptide MHC binding prediction algorithms. Among 442 tumorspecific somatic variants, $\mathbf{5 0}$ missense mutations and $\mathbf{2 0}$ neoepitopes predicted to bind MHC-II were identified. Candidate neoepitopes immunogenicity was assessed by IFN-Y ELISpot after culture of patient's PBMCs in presence of synthetic neopeptides. CD4+ memory $T$ cell responses were detected against a mutated IL-1 $\beta^{5230 F}$ peptide and two additional neoepitopes from HELZ2 ${ }^{\mathrm{V} 241 \mathrm{M}}$ and MLL2 $^{\mathrm{A} 4458 \mathrm{~V}}$ suggesting that efficient anti-tumor immune response occurred in this patient. These results showed that $T$ cells can recognize neoantigens and may lead to the cancer elimination after immunomodulation in the tumor-microenvironment induced by sorafenib. This observation indicates that other immunotherapies in combination with sorafenib could potentially increase the response rate in HCC at advanced stage. 


\section{INTRODUCTION}

Hepatocellular carcinoma (HCC), the most common primary malignant neoplasm of the liver $(85 \%-90 \%)$ [1], is the sixth most frequent cancer in the world and the third cause of cancer-related death [2]. In the majority of patients, the disease is diagnosed at advanced stages and less than $20 \%$ of patients with HCC are eligible for curative treatments. To date, only 3 therapeutic approaches are considered as curative: surgical resection, liver transplantation and percutaneous radiofrequency ablation.

Conventional chemotherapies did not show any significant benefits in the treatment of HCC except for transarterial chemoembolization which allows a slight increase of life expectancy. In advanced stage, sorafenib has been approved as a standard, according to the Barcelona Clinic Liver Cancer (BCLC) staging and its updates [3]. In the Sorafenib HCC Assessment Randomized Protocol (SHARP) phase III trial, patients with advanced HCC were treated with sorafenib or placebo. The median overall survival significantly increased in the sorafenib group compared with the placebo group (10.7 vs 7.9 months, $\mathrm{HR}=0.69 ; 95 \%$ CI:0.55 to $0.87 ; p<0.001)$ [4]. However, there were no complete response in either group and objective responses rates remained poor and were between 2 and 3.3\%.

Sorafenib is an oral multikinase inhibitor that mainly targets kinases involved in tumor cell growth and angiogenesis such as Raf kinases (CRAF, BRAF, V600E BRAF) and tyrosine kinases (FLT3, Kit, VEGFR2/3 and PDGFRB) [5]. In vivo, sorafenib has limited effects on HCC tumor cell proliferation [4]. Nevertheless, sorafenib has the potential to induce a complete remission in few cases (less than 1\%) of advanced HCC cases [6]. Besides, sorafenib's targets, such as c-Kit, VEGFR and FLT-3, are abundantly expressed in immune cells such as regulatory $\mathrm{T}$ cells (Treg) and myeloid-derived suppressive cells (MDSC) $[7,8]$. Sorafenib has thus been implicated in the reduction of Treg and MDSC number and in the lowering levels of immunosuppressive cytokines [9-12]. Moreover, sorafenib has been shown to reduce the immunosuppressive burden by reducing PD-1 expression on circulating T cells $[9,10]$.

During the last decade, evidences of the impact of active antitumor immune response on clinical outcome of HCC patients have been described [13, 14]. CD3+ and $\mathrm{CD} 8+$ cell densities have been significantly associated with a low rate of recurrence and a prolonged relapse-free survival $[15,16]$. Furthermore, high levels of intratumoral and peripheral blood Treg were associated with a higher alpha-fetoprotein (aFP) level, a more advanced TNM stage and a more vascularized tumor [15, 17, 18]. The progressive deficit of CD4+ $\mathrm{T}$ cells functionality induced by FoxP3 + regulatory $\mathrm{T}$ cells was also correlated with poor survival and high recurrence rates in HCC patients $[13,19,20]$.
Antitumor immune response could be driven by the recognition of neoantigens somatically generated by mutations in tumor cells. Interestingly, most of the specific-neoantigen immune responses observed are mediated by $\mathrm{CD} 4+\mathrm{T}$ cells [21] and several studies highlighted a critical role for neoantigen-specific CD4+ T cell responses in tumor elimination [21-23]. Indeed, Tran et al. demonstrated that adoptive transfer of CD4+ T cells specific of ERBB2IP mutation leads to an objective tumor response in metastatic cholangiocarcinoma.

The link between the effects of sorafenib on the immune system and its efficacy in advanced $\mathrm{HCC}$ remains a matter of investigations. We hypothesized that CD4+ T cell antitumor immune response targeting HCC preexists in some patients and that efficacy of immunomodulatory drugs such as sorafenib may be related to their immune status $[24,25]$. To support this hypothesis, we aimed to identify in the present study the immunogenic mutations efficiently recognized by CD4+ T cells in an advanced HCC patient in complete histologic response after sorafenib treatment.

\section{RESULTS}

\section{Complete histologic response induced by sorafenib}

In September 2011, a 51-year-old male patient presented with a large hypervascular liver tumor that measured $20 \mathrm{~cm}$ with satellite nodules disseminated in all the liver segments (Figure 1). A biopsy was performed at the University Hospital of Besançon and the pathologic examination revealed a hepatocellular carcinoma. The patient had no history of cirrhosis and extrahepatic extension assessment was negative. The patient's serum aFP level was $55 \mathrm{ng} / \mathrm{mL}$. In October 2011, sorafenib therapy was initiated at a dosage of $200 \mathrm{mg}$ twice per day and rapidly followed by $400 \mathrm{mg}$ twice per day for 8 months. No side effects were observed expect a moderate grade 1 hand foot syndrome and grade 1 diarrhea that made necessary a temporary reduction of the posology to $200 \mathrm{mg}$ twice per day. After 3 months of treatment a partial response was observed, with a substantial reduction of the tumor burden from 20 to $7.5 \mathrm{~cm}$. After 11 months, a complete surgical resection of the tumor area was achieved and pathologic examination revealed a complete histologic response. Five years later, the patient was still free of disease.

\section{Mutational profiling of the hepatocellular carcinoma}

To identify candidate immunogenic neoantigens, we applied an inverse immunological strategy. A whole exome sequencing (WES) was carried out on the tumor biopsy at diagnosis as well as on autologous normal hepatocytes from the resected liver tissue. The WES identified 
57,430 unfiltered variants in cancer cells (Figure 2A). Variants were found in genes known to be mutated in HCC [26] such as SF3B1, APOB and APOBR. However these genes presented only common SNP mutations thus questioning their implication in oncogenesis. Comparison of the 57,430 variants with normal cells resulted in the identification of 2,585 variants only found in tumor cells and 758 of them had coding mutations. Among them, 442 were somatic tumor specific mutations, and 50 of these being missense mutations (Supplementary Table 1). These 50 mutations were used to establish a list of candidate neoepitopes which could bind patient's MHC-II alleles.

The number of somatic mutations in this patient is in line with the somatic mutation load commonly observed in HCC [27], which is not belonging to the hypermutated cancers group [28]. Among proteins encoded by the 50 missense tumor specific mutated genes, some are reported to be frequently mutated in other cancers in the COSMIC database (accessed in June 2017). For example, MUC16 was found mutated in $7.4 \%$ of cancers $(2225$ mutated out of 30047 tested samples), MLL2 in 4.8\% (1633 out of 34019), FAT1 in 3.81\% (1169 out of 30688) and BAI3 in $2.75 \%$ (823 out of 30208) (Supplementary Table 1). In addition, with the exception of SYK, no clear oncogenic kinase targeted by sorafenib was identified as mutated. Among $50 \mathrm{SNV}$ mutations studied, only three have already been reported in COSMIC database: ANKRD42R119Q, CLMNK488E, FASNR425W, respectively in an endometria carcinoma, skin carcinoma and stomach carcinoma (COSMIC database, 2017-June).

Mutational signature of single-nucleotide variants (SNV) was also studied by analyzing the distribution of each mutation in 96-trinucleotide combinations as described by Alexandrov et al. [27]. Each combination is defined by the substitution class $(\mathrm{C}>\mathrm{A} ; \mathrm{C}>\mathrm{G} ; \mathrm{C}>\mathrm{T} ; \mathrm{T}>\mathrm{A}$; $\mathrm{T}>\mathrm{C} ; \mathrm{T}>\mathrm{G}$ ) and the sequence context immediately $5^{\prime}$ and $3^{\prime}$ to the mutated base (Figure 2B). A mutational signature which does not seem to correspond to any described mutation signature in the COSMIC database (http://cancer. sanger.ac.uk/cosmic/signatures) was identified [27]. This observation suggests a mutational signature with a predominance of $(C>A),(C>T)$ and $(T>G)$ substitutions at trinucleotide motifs in cancer cells, without exceeding $4 \%$ of total SNV.

\section{In silico prediction of tumor-specific neoepitopes}

MHC-II genotyping indicated that the patient is homozygote for HLA-DRB1*1501, HLA-DPB1 ${ }^{*} 0401$ and HLA-DQB1*06. As the magnitude of the HLA-DRrestricted responses have been described as significantly higher than HLA-DP [29], we focused on HLADRB1*1501 to identify candidate neoepitopes. An in silico prediction approach was performed using both Syfpeithi and Immuneepitope algorithms with the protein sequences encoded by the 50 missense cancer-specific mutations. Twenty peptides were predicted to bind HLA-DRB1 ${ }^{*} 1501$ molecules with a binding score $\geq 20$ (Syfpeithi) and/or a percentile rank $<10$ (Immune epitope). The predicted IC50 (nM) of each mutant or WT peptides were reported (Table 1). Several peptides identified are predicted to also bind HLA-DPB1*0401, but not HLA-DQB1 ${ }^{*} 0601$ (data not shown). Some mutations are predicted to enhance the peptide affinity for HLA-DRB1*1501 and HLADPB1 ${ }^{*} 0401$ (i.e.: GABRG2 ${ }^{\text {S306Y }}$, HHIPL1 ${ }^{\text {P386L }}$ and IL$\left.1 \beta^{\mathrm{S} 230 \mathrm{~F}}\right)$, and others do not significantly modify their affinity (i.e.: HELZ2 ${ }^{\mathrm{V} 241 \mathrm{M}}$, MLL2 $2^{\mathrm{A} 4802 \mathrm{~S}}$ and MMP3 ${ }^{\mathrm{R} 303 \mathrm{~S}}$ ) (Table 1).

\section{Identification of immunogenic tumor-associated neoepitopes}

The ability of the selected neopeptides to stimulate CD4+ $\mathrm{T}$ cells was then tested. For this purpose, lymphocytes isolated from patient's peripheral blood were stimulated in vitro using a pool of neopeptides (Table 1). $\mathrm{T}$ cells secreted IFN- $\gamma$ against pool-1, -2 and -3 while

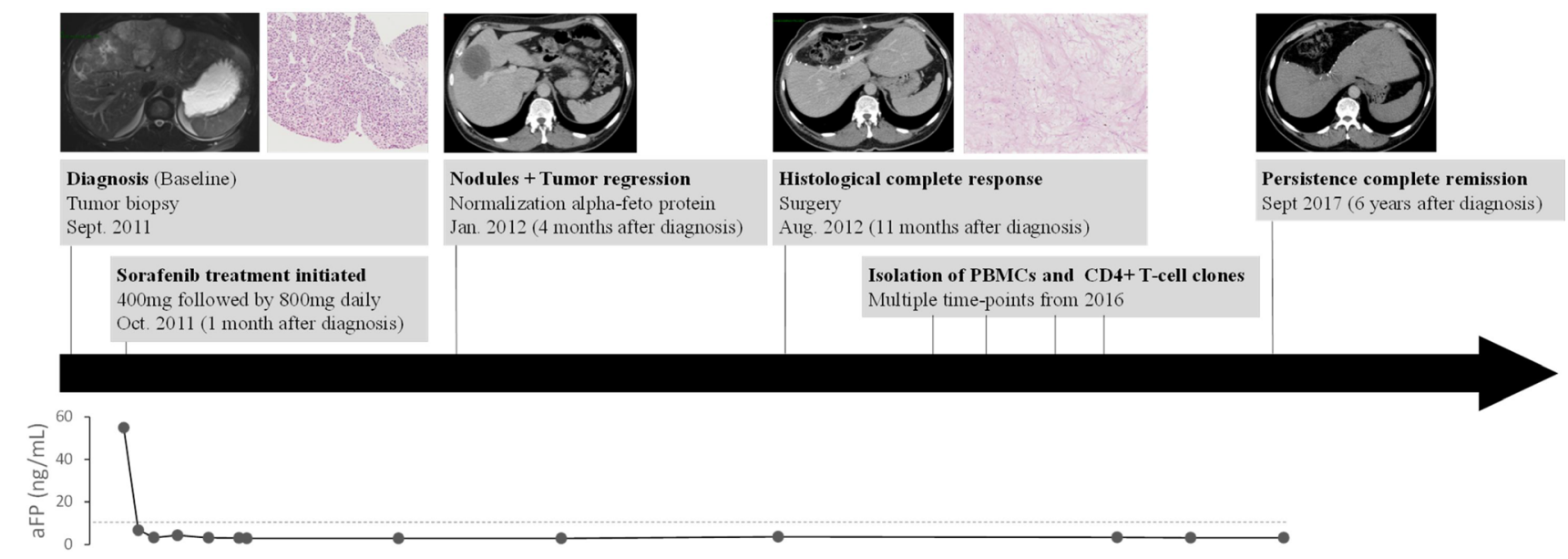

Figure 1: Patient's history. Timeline of diagnosis and treatment of hepatocarcinoma patient showing magnetic resonance imaging, scanner imaging and alpha fetoprotein (aFP) level at several times of pathology history. 
no response was observed against pool-4 (Figure 3A). To identify which specific neoepitopes within neopeptide pools stimulated T-cells, we deconvoluted all stimulatory pools (Figure 3B-3D). Peptides named 49, 51, both from pool-2, and 53 from pool-3 were identified as immunogenic. No immunogenic peptides could be identified from pool-1. Thus, patient's PBMC recognized at least three neopeptides named 49, 51 and 53 corresponding to HELZ2 ${ }^{\mathrm{V} 241 \mathrm{M}}$ (Helicase with zinc finger domain 2), IL-1 $\beta^{\mathrm{S} 230 \mathrm{~F}}$ (Interleukine-1 $\beta$ ) and MLL2 ${ }^{\mathrm{A} 4802 \mathrm{~S}}$ (Histone-lysine N-methyltransferase 2D) mutations (Supplementary Table 1). Interestingly, neopeptides 51 and 53 are predicted to have a better binding affinity for HLA-DRB1*1501 and HLA-DPB1*0401 than their wild type (WT) counterpart. They are also predicted to have a better binding affinity for HLA-DRB1* 1501 than for HLA-DPB ${ }^{*}$ 0401. Among the neopeptides selected, based on the percentile rank, IL-1 $\beta^{\mathrm{S} 230 \mathrm{~F}}$ (FEFAQFPNWYISTS) and MLL2 ${ }^{\mathrm{A} 4802 \mathrm{~S}}$ (SGHLLLQKLLRAKNV) mutated peptides on HLA-DRB $1{ }^{*} 1501$ corresponded to the second and sixth better binders respectively. In contrast HELZ2 ${ }^{\mathrm{V} 241 \mathrm{M}}$ (RMQAASFGTFEQWVV) mutated peptide corresponds to the thirteenth for HLA-DRB1*1501 and the third for HLADPB1*0401.

\section{Detection of CD4+ memory $\mathrm{T}$ cell responses against tumor-specific neoantigens}

To evaluate the mutation specificity of the $\mathrm{T}$ cell recognition, $\mathrm{T}$ cells were stimulated by the mutated peptide or its WT counterpart (Table 1). Based on binding prediction IL-1 $\beta^{\mathrm{S} 230 \mathrm{~F}}$ seemed to be a neoagretope with an IC50 of $29.55 \mathrm{nM}$ for the mutated peptide versus $277.35 \mathrm{nM}$ for the WT peptide in the HLA-DRB1*1501 context, and $235.6 \mathrm{nM}$ for the mutated peptide versus $338.9 \mathrm{nM}$ for the WT peptide in the HLA-DPB $1^{*} 0401$ (Table 1). However, while $\mathrm{T}$ cells recognized the three mutated peptides: HELZ2 $2^{\mathrm{V} 241 \mathrm{M}}$, IL-1 $\beta^{\mathrm{S} 230 \mathrm{~F}}$ and MLL2 ${ }^{\mathrm{A} 4802 \mathrm{~S}}$, only IL-1 $\beta$ was recognized among the WT peptides (Figure $4 \mathrm{~A}$ and $4 \mathrm{~B})$. Nonetheless, IL- $1 \beta^{\mathrm{S} 230 \mathrm{~F}}$ was able to stimulate specific immune responses with much more efficiency than the corresponding WT peptide as the number of IFN- $\gamma$ secreting T cells was 3.8 times higher (Figure 4B). HELZ2 ${ }^{\mathrm{V} 241 \mathrm{M}}$ and MLL2 ${ }^{\mathrm{A} 4802 \mathrm{~S}}$ which were not predicted to increase HLA binding affinity for HLA-DRB1*1501 (Figure 4C) and HLA-DPB1*0401 (Figure 4D) may be implicated in the TCR-HLA/peptide recognition. Overall, we demonstrated the presence of tumor-specific CD4+ memory $\mathrm{T}$ cell responses against 3 neopeptides, IL-1 $\beta^{\mathrm{S} 230 \mathrm{~F}}$, HELZ2 ${ }^{\mathrm{V} 241 \mathrm{M}}$ and MLL2 $2^{\mathrm{A} 4802 \mathrm{~S}}$.

\section{CD4+ $T$ cell recognition of processed mutant proteins and HLA restriction}

To further characterize these responses, the isolation of neopeptide-specific CD4+ T-cell clones was realized after a step of IFN- $\gamma+$ cell sorting assay. Clones were successfully obtained from HELZ2 ${ }^{\mathrm{V} 241 \mathrm{M}}$ peptide stimulated PBMCs but not from the two other T cell lines. As shown

A

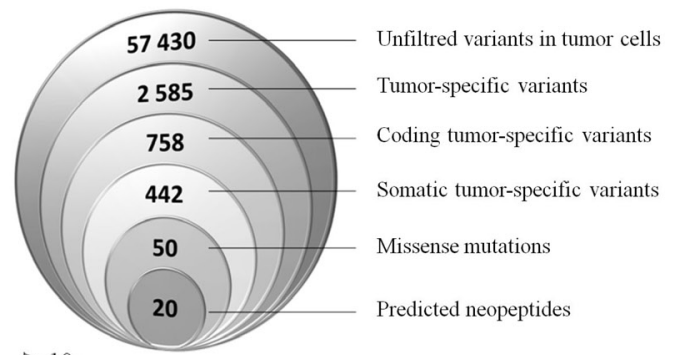

B

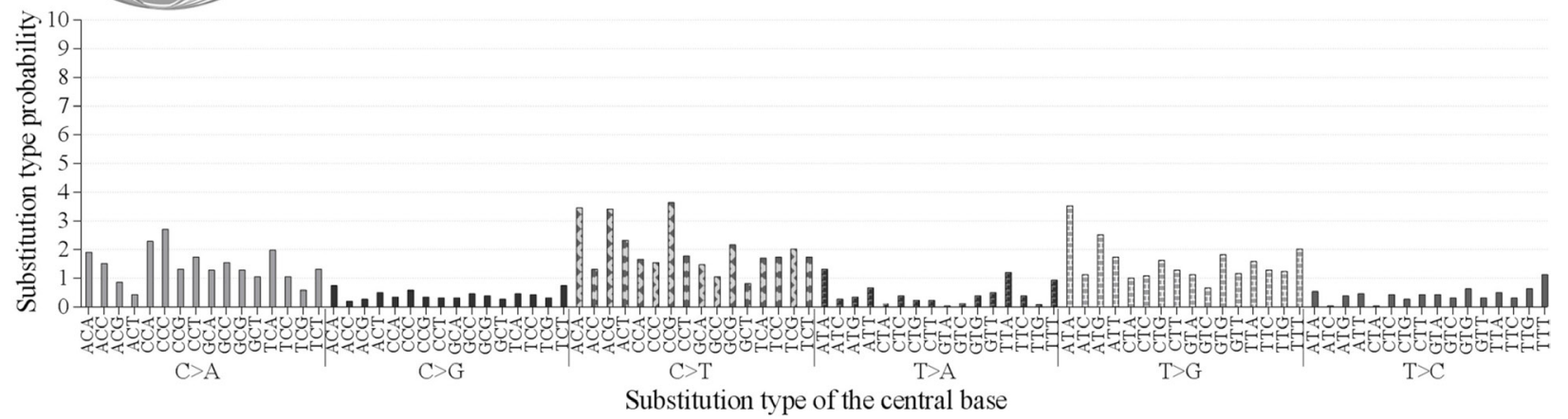

Figure 2: Mutations in patient's hepatocarcinoma. (A) Identification of suitable neoepitopes by reverse immunology. Venn diagram (from left to right): Number of mutations detected in tumor sample by WES. Number of tumor-specific variants, somatic tumorspecific variants and missense mutations found to be expressed. Finally, number of neopeptides predicted to bind to HLA-DRB1*15:01 with a binding score $\geq 20$ (Syfpeithi) and/or a percentile rank $<10$ (Immune epitope). (B) Pattern of signatures of the mutational processes operative in HCC exome. The mutational signature is displayed using a 96-substitution classification defined by the substitution class and the sequence context immediately $3^{\prime}$ and $5^{\prime}$ to the mutated base. 


\begin{tabular}{|c|c|c|c|c|c|c|c|c|c|}
\hline & $\begin{array}{l}\text { Peptide } \\
\text { names }\end{array}$ & $\begin{array}{c}\text { Gene } \\
\text { names }\end{array}$ & Protein names & Mutated/WT peptides & $\begin{array}{l}\text { Mutated/ } \\
\text { WT binding } \\
\text { score }\end{array}$ & $\begin{array}{c}\text { Mutated/WT } \\
\text { percentile } \\
\text { rank }\end{array}$ & $\begin{array}{l}\text { Mutated/WT } \\
\text { IC50 (nM) }\end{array}$ & $\begin{array}{l}\text { Mutated/WT } \\
\text { percentile } \\
\text { rank }\end{array}$ & $\begin{array}{l}\text { Mutated/WT } \\
\text { IC50 (nM) }\end{array}$ \\
\hline \multirow{6}{*}{ Pool-1 } & 42 & ANKRD42 & $\begin{array}{l}\text { Ankyrin repeat domain } \\
\text { containing protein } 42\end{array}$ & TLQIML(Q/R)SGVDPSVT & $24 / 24$ & $11.84 / 11.73$ & $637.7 / 605.95$ & $67.88 / 66.37$ & $9676.4 / 14367.5$ \\
\hline & 43 & C5orf60 & $\begin{array}{l}\text { Putative uncharacterized } \\
\text { protein c5orf60 }\end{array}$ & QAEVGEWLRI(R/G)NKYI & $30 / 30$ & $2.33 / 2.36$ & $27.8 / 43.45$ & $54.76 / 63.1$ & $5470.3 / 8301.65$ \\
\hline & 44 & CRAMP1L & Protein crampedlike & Y(K/E)HGKDFEAIQNNIA & $24 / 24$ & $12.18 / 13.55$ & $2184.7 / 2301.2$ & $54.99 / 57.82$ & $5768.8 / 6145.7$ \\
\hline & 45 & $\mathrm{DBC} 1$ & $\begin{array}{l}\text { Cell cycle and apoptosis } \\
\text { regulator protein } 2\end{array}$ & ISDVQVF(W/G)YSLRFNA & $24 / 24$ & $6.47 / 1.91$ & $228.95 / 222.1$ & $2.21 / 14.5$ & $268.1 / 1198.2$ \\
\hline & 46 & DCAF4L2 & $\begin{array}{c}\text { DDB1 and CUL4 } \\
\text { associated factor } 4 \text { like } \\
\text { protein } 2\end{array}$ & SLSIHAYHSFST(S/G)LS & $34 / 34$ & $0.80 / 0.83$ & $50.85 / 55.45$ & $16.5 / 20.02$ & $670.45 / 1009.95$ \\
\hline & 47 & FAT1 & Protocadherin Fat 1 & LNRKILYSLIDSAD(E/G) & $20 / 20$ & $10.06 / 8.41$ & $405.6 / 364.9$ & $32.52 / 33.85$ & $2508.4 / 2655.6$ \\
\hline \multirow{5}{*}{ Pool-2 } & 48 & GABRG2 & $\begin{array}{l}\text { Gamma-aminobutyric } \\
\text { acid receptor subunit } \\
\text { gamma-2 }\end{array}$ & AVPART(Y/S)LGITTVLT & $24 / 14$ & $7.39 / 32.28$ & $514.9 / 2106.4$ & $10.8 / 57.49$ & $1154.75 / 9219.3$ \\
\hline & 49 & HELZ2 & $\begin{array}{l}\text { Helicase with zinc } \\
\text { finger domain } 2\end{array}$ & $\begin{array}{c}\mathrm{R}(\mathrm{M} / \mathrm{V}) \\
\text { QAASFGTFEQWVV }\end{array}$ & $24 / 24$ & $9.04 / 9.04$ & $335.5 / 336.45$ & $4.05 / 4.05$ & $353.2 / 369.35$ \\
\hline & 50 & HHIPL1 & HHIP-like protein 1 & $\begin{array}{c}\text { AAQ(L/P) } \\
\text { EVYALGVRNMW }\end{array}$ & $24 / 14$ & $9.46 / 24.22$ & $316.7 / 901.25$ & $36 / 52.56$ & $5077 / 9003.8$ \\
\hline & 51 & IL1B & Interleukin 1 beta & EFE(F/S)AQFPNWYISTS & $26 / 18$ & $0.62 / 18.71$ & $29.55 / 277.35$ & $2.67 / 6.5$ & $235.6 / 338.9$ \\
\hline & 52 & JARID2 & $\begin{array}{l}\text { Jumonji And AT-Rich } \\
\text { Interaction Domain } \\
\text { Containing } 2\end{array}$ & HKCI(C/Y)KGRSVSLTTF & $24 / 24$ & $11.51 / 6.48$ & $865.9 / 327.8$ & $53.58 / 35.27$ & $12181.85 / 3751.35$ \\
\hline \multirow{5}{*}{ Pool-3 } & 53 & & Histone-lysine & (S/A)GHLLLQKLLRAKNV & $20 / 20$ & $2.84 / 2.87$ & $116.4 / 117.3$ & $15.34 / 14.44$ & $688.4 / 659.85$ \\
\hline & 54 & MLL2 & $\mathrm{N}$-methyltransferase 2D & MV(V/A)VAELLSMKIPNS & $24 / 24$ & $2.28 / 3.75$ & $94.95 / 101.05$ & $16.21 / 20.76$ & $1608.15 / 2029.7$ \\
\hline & 55 & MMP3 & Stromelysin-1 & (S/R)GEILIFKDRHFWRK & $20 / 20$ & $0.52 / 0.47$ & $25.6 / 24.8$ & $10.59 / 10.36$ & $591.2 / 586.5$ \\
\hline & 56 & OR51V1 & Olfactory receptor $51 \mathrm{~V} 1$ & TMAFDRYIAICNP(V/L)R & $32 / 32$ & $4.19 / 4.55$ & $180.65 / 171.65$ & $12.76 / 11.68$ & $602 / 564.1$ \\
\hline & 57 & PCDHGB7 & $\begin{array}{l}\text { Protocadherin } \\
\text { gammaB7 }\end{array}$ & LFLLAVILAIAL(C/R)LR & $24 / 24$ & $0.8 / 0.79$ & $663.85 / 54.95$ & $11.88 / 11.88$ & $1141.95 / 1132.05$ \\
\hline \multirow{4}{*}{ Pool-4 } & 58 & PCK1 & $\begin{array}{l}\text { Phosphoenolpyruvate } \\
\text { carboxykinase, cytosolic }\end{array}$ & VARIESK(M/T)VIVTQEQ & $20 / 20$ & $8.49 / 8.49$ & $370.55 / 656.2$ & $36.51 / 61.89$ & $7447.6 / 11284.9$ \\
\hline & 59 & RHOBTB1 & $\begin{array}{c}\text { Rho-related BTB } \\
\text { domain-containing } \\
\text { protein } 1\end{array}$ & SVQPG(H/P)FRTLLQFLY & $24 / 24$ & $11.51 / 11.51$ & $264.5 / 369.45$ & $4.27 / 6.48$ & $366.1 / 433.6$ \\
\hline & 60 & SLC38A4 & $\begin{array}{l}\text { Sodium-coupled neutral } \\
\text { amino acid transporter } 4\end{array}$ & DELLHAYS(E/K)VYTLDI & $30 / 30$ & $5.76 / 1.5$ & $119.6 / 63.55$ & $5.9 / 4.73$ & $640.95 / 672.95$ \\
\hline & 62 & PNPLA7 & $\begin{array}{c}\text { Patatin-like } \\
\text { phospholipase domain- } \\
\text { containing protein7 }\end{array}$ & A(S/A)AGPLLKRSHSVPA & $4 / 4$ & $8.83 / 8.81$ & $504.8 / 504.65$ & $66.42 / 62.81$ & $12199.95 / 11120.4$ \\
\hline
\end{tabular}

Abbreviations: WT, wild type.

Candidate peptides from mutated proteins are selected for their predicted capacity to bind HLA-DRB1 ${ }^{*} 1501$ using prediction algorithms SYFPEITHI (binding score) and Immune epitope database and binding prediction (IEDB) (percentile rank and IC50 (nM)). These 20 candidate neopeptides are divided into 4 pools, from 1 to 4 . The IEDB consensus tool was also used to predict HLA-DPB1*0401 binding peptides.

in Figure 5A, CD4+ T cell clones were only able to recognize the HELZ2 ${ }^{\mathrm{V} 241 \mathrm{M}}$ neopeptide (49) and not the $\mathrm{IL}^{-1} \beta^{\mathrm{S} 230 \mathrm{~F}}(51)$ or MLL2 $2^{\mathrm{A} 4802 \mathrm{~S}}$ (53) neopeptides. In addition, we showed that the clones stimulated by HELZ2 ${ }^{\mathrm{V} 241 \mathrm{M}}$ neopeptide mainly produced IFN- $\gamma$ and IL-2, in agreement with a Th1 polarization (Figure 5B). Thus, these results showed that HELZ2 ${ }^{\mathrm{V} 241 \mathrm{M}}$-specific CD4+ T-cell clones can be generated from the patient's peripheral blood and were Th1 polarized. To further identify the HLA context of this recognition we co-cultured a HELZ2 ${ }^{\mathrm{V} 241 \mathrm{M}}$-specific CD4+ T cell clone with pan HLA-DR, HLA-DP and HLADQ blocking antibodies. While no difference of IFN- $\gamma$ secretion was found between control and pan HLA-DQ or -DR blocking antibodies, IFN- $\gamma$ secretion was completely 
abrogated in presence of pan HLA-DP blocking antibodies (Figure 5C). The patient being HLA-DPB1 ${ }^{*} 04$ homozygous, the $\mathrm{CD} 4+\mathrm{T}$ cell clone recognize the HELZ2 ${ }^{\text {V241M }}$ peptide in the HLA-DPB $1^{*} 04$ context. Thus, these results implied that memory HELZ2 $2^{\mathrm{V} 241 \mathrm{M}} / \mathrm{HLA}$ DPB $1^{*} 04$ specific CD4+ T cells were present in patient's blood. Finally, HELZ2 ${ }^{\mathrm{V} 241 \mathrm{M}}$-specific CD4+ T-cell clones were stimulated by HLA-DPB1*04 expressing B-EBV pulsed with a range of peptide concentrations from 100 to $10^{-7} \mu \mathrm{M}$. The EC50 of IFN- $\gamma$ secretion was observed at peptide concentration of $500 \mathrm{nM}$ of HELZ2 $2^{\mathrm{V} 241 \mathrm{M}}$ peptide whereas no IFN- $\gamma$ was produced in response of HELZ2 WT (Figure 5D). Despite of the low T cell clone avidity, co-culture assays were realized with allogenic MoDC to assess the processing of the HELZ2 ${ }^{\mathrm{V} 241 \mathrm{M}}$ peptide. MoDC were pulsed with cell lysate of $\mathrm{SiHa}$ cell line transfected with Tandem MiniGene (TMG) -1 or -2 and co-culture overnight with CD4+ T cell clones. These TMG encode a tumor immunogenic neoantigens in Sorafenib-responsive HCC protein control (TMG-1) or a protein including a 35 mer peptide encompassing HELZ2 ${ }^{\mathrm{V} 241 \mathrm{M}}$ mutation

A

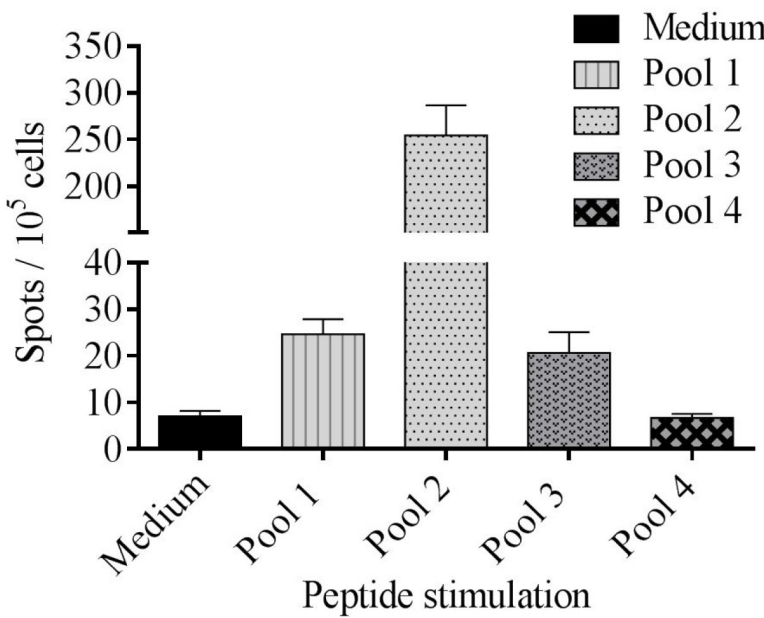

C

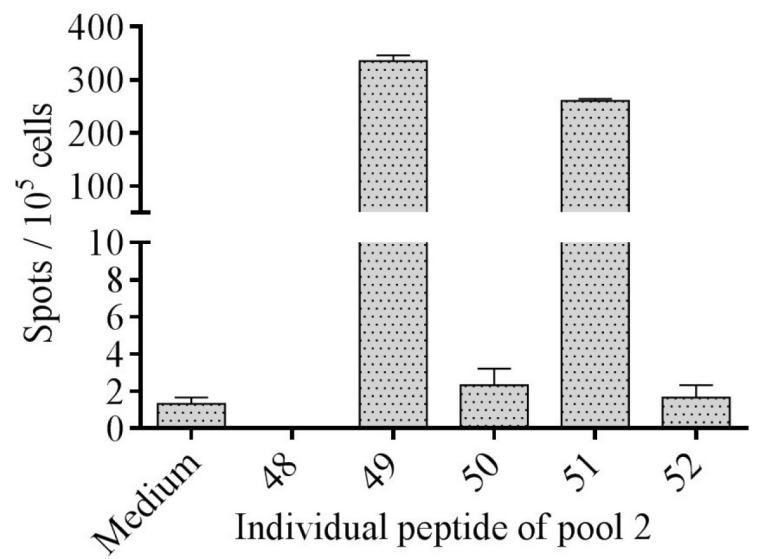

(TMG-2). IFN- $\gamma$ ELISA of these co-culture revealed that HELZ2 ${ }^{\mathrm{V} 241 \mathrm{M}}$ peptide is efficiently processed and presented to CD4+ T-cell (Figure 5E).

\section{DISCUSSION}

In an attempt to better understand the factors involved with the effectiveness of the sorafenib treatment in $\mathrm{HCC}$, we carried out a study in a patient with an advanced HCC treated with this molecule that experienced a complete histological response. Despite a moderate overall survival improvement, sorafenib is a standard for advanced HCC, according to the Barcelona criteria. Several studies demonstrated the critical importance of tumor immunity in the effectiveness of immunotherapy in HCC [16, 17, 30-32]. Sorafenib has been shown to have immunomodulatory properties, by enhancing the activity of tumor-specific $\mathrm{T}$ cell and by reducing the suppressive immune cell populations such as Treg and MDSC $[11,12]$. Of note, a study by Cabrera et al. showed that sub-pharmacologic doses of sorafenib impact subsets of

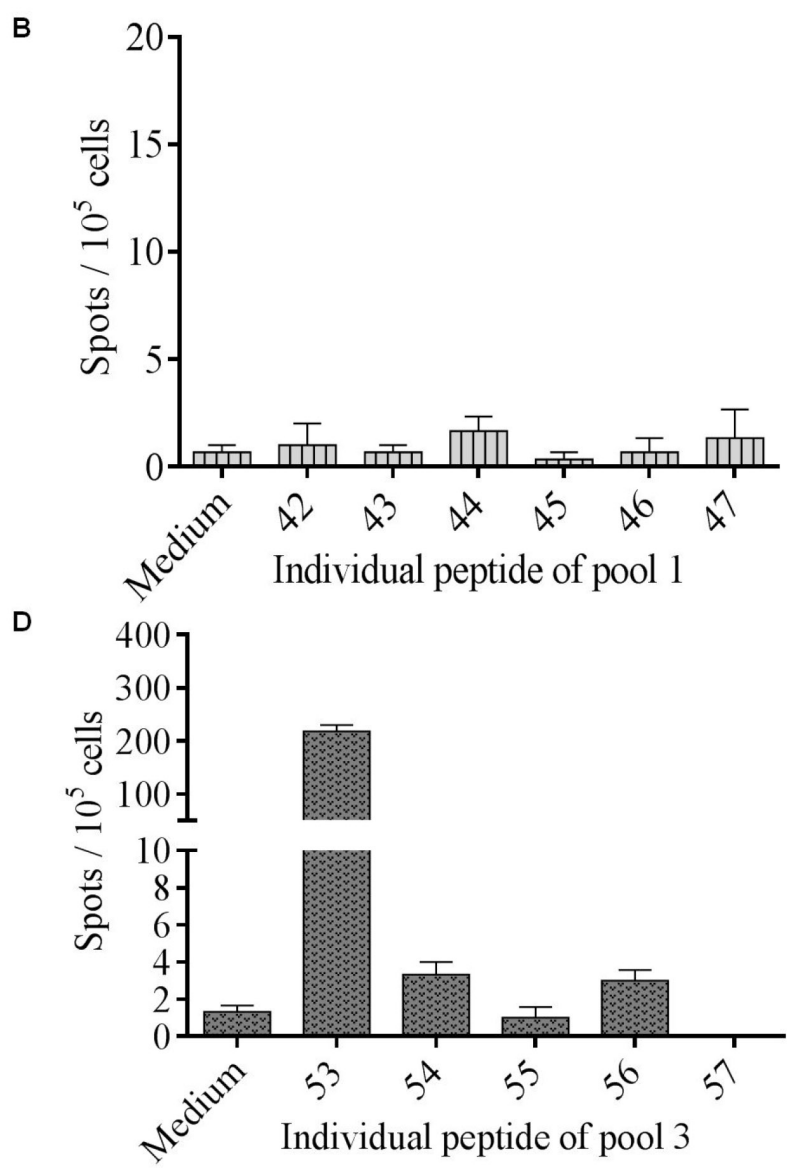

Figure 3: Identification of immunogenic tumor-associated neoepitopes. (A) PBMC were cultured during 12 days with 4 pools of mutated peptides $(2 \mu \mathrm{M})$ and the T cell reactivity was detected by IFN- $\gamma$ ELISpot assay. Columns represent the mean of triplicate of IFN- $\gamma$ spots number for $10^{5}$ cells; bars, SEM. (B-D) To assess mutated peptides-specific immune responses, PBMC were stimulated overnight with each pool separately. Neopeptides were tested individually among positive immune response inducing peptide pools: pool 1 (B), pool 2 (C) and pool 3 (D). 
$\mathrm{T}$ cells increasing effector $\mathrm{T}$ cells from patient's HCC, while blocking Treg function [10].

The interest of combining next-generation sequencing of cancer DNA with reverse immunology to identify $\mathrm{T}$ cell epitopes have been highlighted in recent publications [33, 34]. It has been shown that a unique tumor neoantigen could favor the elimination of cancer cell by $\mathrm{T}$ cells in mouse model [35] but also in human cancers [36]. Despite the apparent low frequency of tumor-reactive $\mathrm{T}$ cells in gastrointestinal cancer [37] and the intermediate mutation prevalence in HCC $[27,38]$, the strategy reported here leads to successful isolation of neoantigen-reactive $\mathrm{T}$ cells from peripheral blood. WES performed on patient's normal and cancer cells had allowed to identify tumor-specific mutations. Mutation immunogenicity analysis has been focused on missense mutations, the most studied mutation type. However, out of frame and splice site mutations may be more immunogenic [39]. As far as we know, this is the first WES performed on a sorafenib-responsive HCC patient. MUC16 which was found to have an impact on the cancer immunogenicity and has been shown to be implicated in the inactivation of NK cells and monocytes [40] was found mutated. Moreover a recent study of Balachandran et al. identified MUC16 neoantigens in long-term survivors of pancreatic cancer [41]. However, the MUC16 mutation expressed by the patient's tumor cells does not seem to be presented by its HLA class II molecules as low binding capacities were predicted. In our study, several mutated genes encoding proteins of which mutated peptides are predicted to bind patient's HLA class II were identified. Three out of 20 neopeptides were recognized by patient's PBMC suggesting the presence of tumor-specific $\mathrm{CD} 4+\mathrm{T}$ cell memory responses, potentially implicated in $\mathrm{HCC}$ elimination. Although the three immunogenic mutations (HELZ2 ${ }^{\mathrm{V} 241 \mathrm{M}}$, IL-1 $\beta^{\mathrm{S} 230 \mathrm{~F}}$ and MLL2 ${ }^{\mathrm{A} 4802 \mathrm{~S}}$ ) identified had never been described so far, these genes are known to be mutated in HCC [28]. MLL2 is a histone methyltransferase described as driver mutation in numerous cancer types $[33,42,43]$. Its oncogenic mechanism is unclear but it was demonstrated that mutation of MLL2 in mouse cells resulted in genomic instability [44]. HELZ2 is a protein implicated in the peroxisome activity and the proliferation of tumor cells via PPAR- $\delta$ pathway activation. IL- $1 \beta$ is a pro-inflammatory cytokine activating the MAP kinase pathway and was reported as a potential marker influencing HCC progression from stage III to stage IV [45]. T cell responses specific of HELZ2 ${ }^{\mathrm{V} 241 \mathrm{M}}$ and MLL2 ${ }^{\mathrm{A} 4802 \mathrm{~S}}$ were only found against mutated peptides
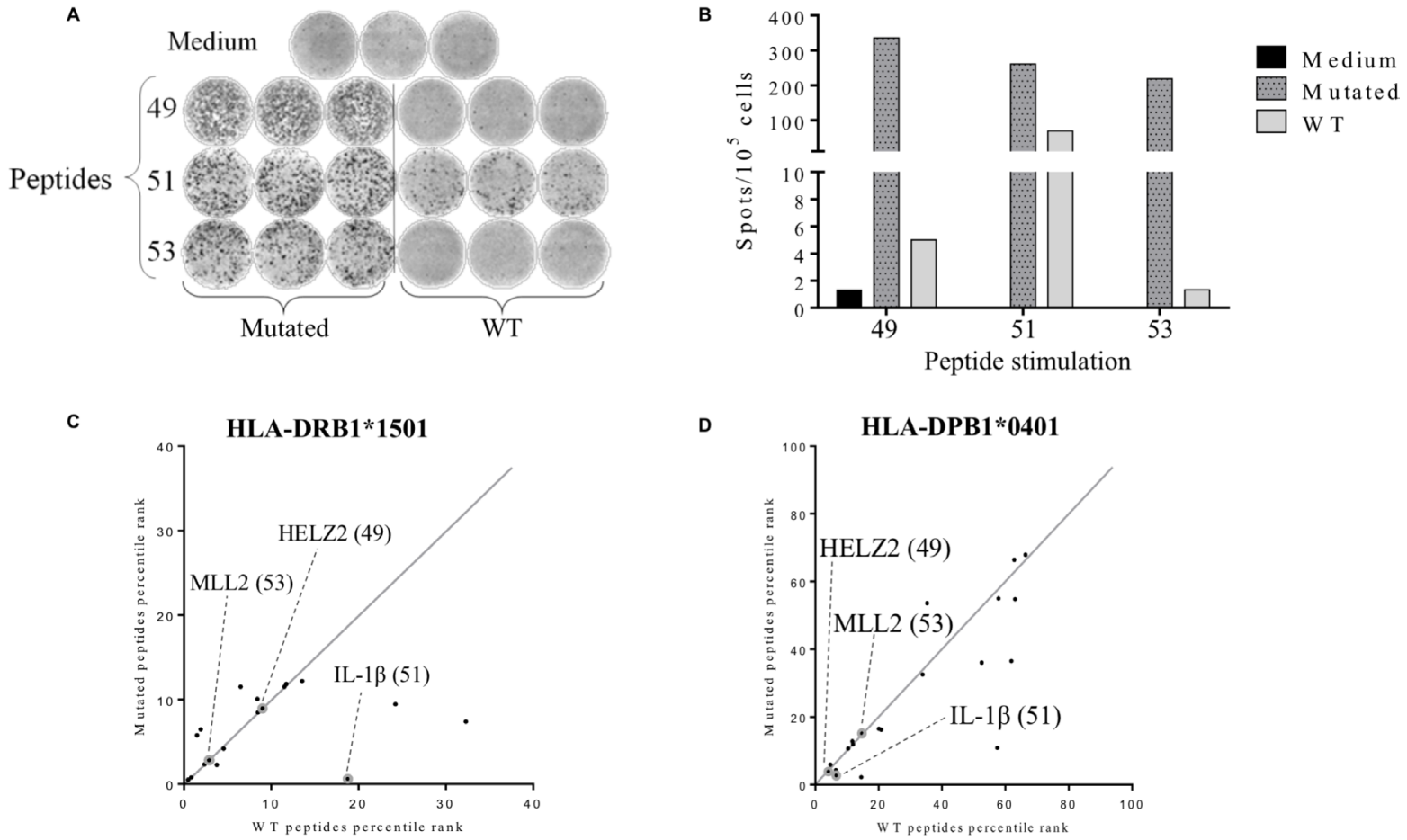

Figure 4: Detection of tumor-associated neopeptides-specific CD4+ T cell responses. The secretion of IFN- $\gamma$ in patient's PBMCs was assessed after 12 days of stimulation by mutated or corresponding wild type (WT) peptides $(2 \mu \mathrm{M})$ and the T cells reactivity against the peptides was detected by IFN- $\gamma$ ELISpot assay as described in material and methods. Cells cultured in presence of medium were used as negative control (A) Illustration of medium, mutated and WT peptides IFN- $\gamma$ ELISpots wells. (B) Histogram represents the mean of triplicate of IFN- $\gamma$ spots number for $10^{5}$ cells. (C-D) Comparison between the predicted binding score of the wild type peptide with the corresponding mutated peptide for HLA-DRB1 ${ }^{*} 1501$ allele (C) and HLA-DPB1 ${ }^{*} 0401$ allele (D). Grey circles represent the identified immunogenic neopeptides: HELZ2 ${ }^{\mathrm{V} 24 \mathrm{M}}$ (49), IL-1 ${ }^{\mathrm{S} 230 \mathrm{~F}}$ (51) and MLL2 ${ }^{\mathrm{A} 4802 \mathrm{~S}}$ (53). 
and not against their wild-type counterparts. These data confirmed a study by Ott et al. [23] which found that $86 \%$ of $\mathrm{T}$ cell lines were preferentially reactive against the mutated compared to the corresponding wildtype peptide.

Only HELZ2 ${ }^{\mathrm{V} 241 \mathrm{M}}$-specific CD4 T cell clones could be isolated. This may be due to the long-term expansion required to achieve sufficient cell numbers for analysis which decreases the frequency of lower proliferative T cells [23]. Previous studies showed that HLA-DR are the most immunogenic HLA class II molecules and especially compared to HLA-DPB $1^{*} 04$ [46]. However, despite the selection of neoantigens on the basis of predicted HLA$\mathrm{DRB}^{*} 1501$ binding affinity, HELZ2 ${ }^{\mathrm{V} 241 \mathrm{M}}$-specific T cell clones were restricted by HLA-DPB1*0401. This may be due to the lower MHC-II binding affinity required for CD4 T activation [47] and to the MHC-II peptide binding groove structure that allows more promiscuous binding of peptides [48, 49]. This result also highlights the work that is still needed to be done to improve HLA class II binding algorithms. It is thus important to select candidate epitopes by testing several HLA-binding prediction and algorithms. Our selection process may induce a potential loss of immunogenic neopeptides, but it has permitted to drastically reduce the number of tested neopeptides and to isolate 3 immunogenic neopeptides among 20 selected candidates. This number of immunogenic neopeptides is in line with the 2-4 immunogenic peptides per patient previously found in another study by Ott et al. [23]. The absence of HELZ2 and MLL2 WT peptides immunogenicity, suggests that somatic mutations of these proteins might generate a neoepitope. Furthermore, the WT peptides present a similar capacity to bind HLA molecules than their mutated peptides counterpart. These results suggest an implication of the mutation in the direct interaction between the peptide and the TCR. Based on binding predictions it was unlikely to found a $\mathrm{T}$ cell response against IL-1 $\beta$ WT peptide as it presented a low affinity for HLA-DPB1 ${ }^{*} 0401$ (338.9 nM) and HLADRB1*1501 (277.35 nM). However, it was described that 8 out of 10 neoepitopes with a low affinity $(>500 \mathrm{nM})$, induced a tumor rejection in tumor mouse model after immunization [50]. Moreover, if tumor material had been available, it would have been interesting to analyze neoepitope recognition by tumor infiltrating lymphocyte (TIL) as it recently highlighted a higher predicted affinity of TIL than their blood counterpart in ovarian cancer [51].

In the present study, antitumor immune responses have only been evaluated after remission and not before or during patient's treatment. Another limitation of our work is the absence of data regarding the expression
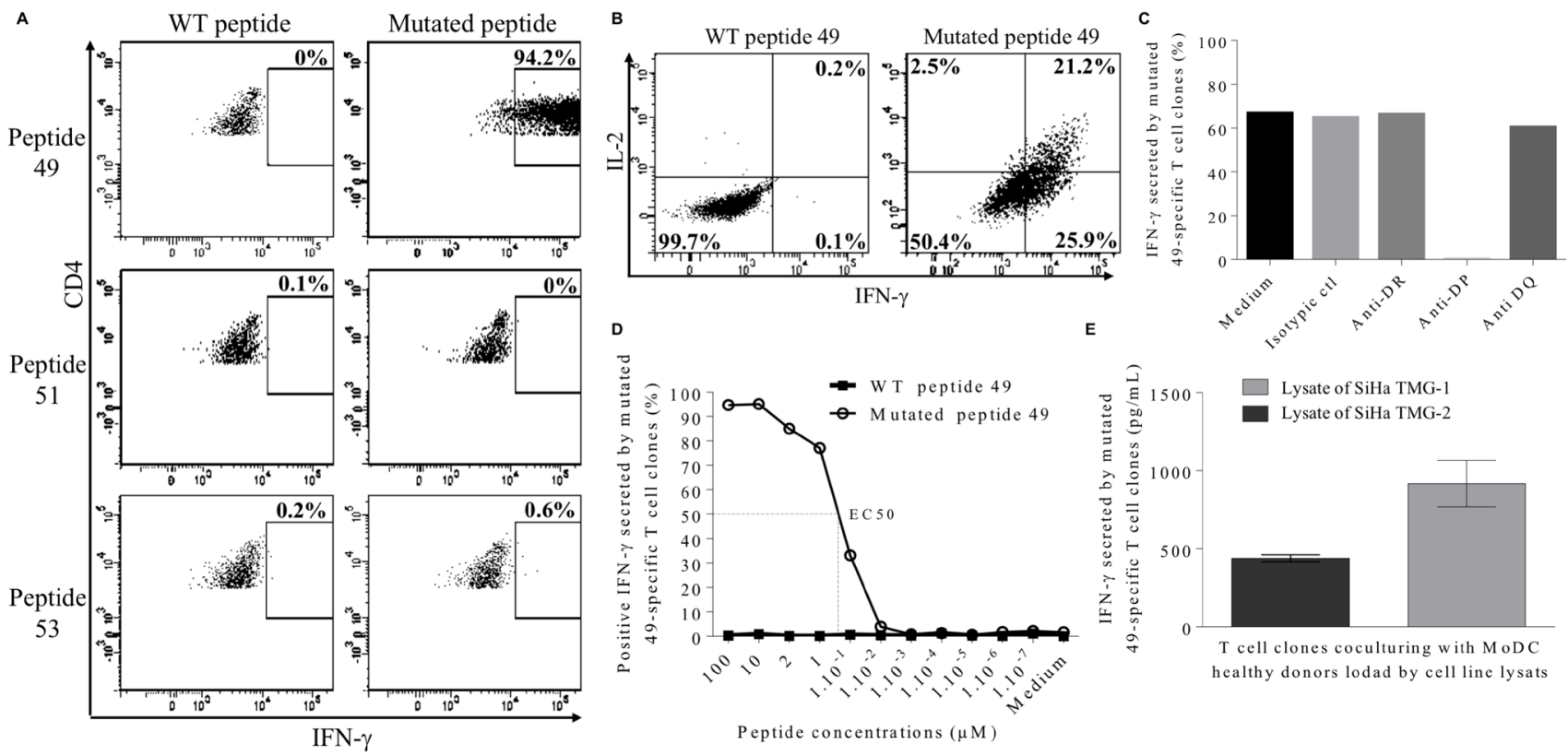

Figure 5: Characterization of neopeptide 49-specific CD4 T cell clones. (A) Percentage of IFN- $\gamma$-producing CD4 T cell clone in response to $2 \mu \mathrm{M}$ of neopeptide 49, neopeptide 51 or neopeptide 53. (B) Secretion of IFN- $\gamma$ and IL-2-by CD4 T cell clone in response to $2 \mu \mathrm{M}$ of HELZ2-derived WT peptide 49 (left) versus mutated peptide 49 (right). (C) Neopeptide 49-specific CD4 T cell clones were treated with blocking antibodies (anti- HLA-DP, anti-HLA-DR or anti-HLA-DQ) or with an isotype control before stimulation with HELZ2 ${ }^{\mathrm{V} 241 \mathrm{M}}$ neopeptide. CD4 $\mathrm{T}$ cell clones reactivity was assessed by intracellular IFN- $\gamma$ staining. (D) CD4 T cell clones were cultured in presence of B-EBV cell line loaded with increasing doses of neopeptide 49 (empty circle) and their reactivity was assessed by intracellular IFN- $\gamma$ staining. Stimulation with WT peptide-loaded B-EBV is used as negative control (black triangle). (E) HLA-DRB1*04 positive allogenic MoDC loaded with tumor cell lysates from SiHa cell line transfected with TMG-1 control vector or TMG-2 vector encoding the HELZ2 $241 \mathrm{M}$ mutation were cocultured with neopeptide 49-specific CD4 T cell. Reactivity of neopeptide 49-specific CD4 T cell clones was evaluated by IFN- $\gamma$ ELISA. Results are shown as mean of IFN- $\gamma$ levels; bars, SEM. 
of the mutated proteins. Nonetheless, in the present study we identified memory $\mathrm{T}$ cell responses for all these 3 immunogenic peptides 5 years after remission, which supports the idea that these proteins were expressed by tumor cells. The neoepitopes identified may thus be implicated in the enhancement of the tumor immunogenicity [23, 35, 36]. Indeed, memory T-cell responses mostly reveal dominant epitopes [52]. However we cannot assert that HELZ2 $2^{\mathrm{V} 241 \mathrm{M}}$, IL-1 $\beta^{\mathrm{S} 230 \mathrm{~F}}$ and MLL2 ${ }^{\mathrm{A} 4802 \mathrm{~S}}$ specific CD4+ T cell responses were sufficient to induce the elimination of the whole tumor cells observed during the complete response. The correlation between neoantigens specific- $\mathrm{T}$ cell response and the postsurgery survival in HCC has never been studied and deserves further investigations [35, 36, 53].

The ability of $\mathrm{T}$ cells to target unique mutations in HCC efficiently treated by sorafenib is an additional clue to extend immunotherapies to HCC patients. This observation, along with a study by Kalathil et al. suggesting that $\mathrm{T}$ cell responses preexisting in $\mathrm{HCC}$ were inhibited by $\mathrm{PD}-1$, reinforces the idea that analyzing the PD-1 expression on circulating HCC-specific $T$ cells would be useful to establish new immunotherapy strategies in HCC [9]. Thus, it may also be possible to identify potential sorafenib-responsive patients by identifying the PD-1 expression in circulating T cells. Finally, these data along with the present study of a great responder patient suggest a therapeutic potential for an anti-PD-1/PD-L1 immunotherapy combined to sorafenib treatment known to decrease the immunosuppressive burden in the context of advanced HCC [9].

In conclusion, in the light of the results of recent studies on the efficacy of immunotherapies in HCC, our data from a great responder patient suggest a therapeutic potential for immune checkpoint blockade in combination with sorafenib to decrease the immunosuppressive burden and reach a higher response rate in advanced HCC $[31,54,55]$.

\section{MATERIALS AND METHODS}

\section{Patient}

Hepatocellular carcinoma patient (HCC) was recruited through the Department of Medical Oncology of the University Hospital of Besançon (France). The patient was enrolled after the signature of informed consent, and after approval by the local ethics committee.

\section{DNA extraction}

Tumor genomic DNA was extracted from formalinfixed paraffin-embedded (FFPE) using QIAamp DNA FFPE Tissue Kit (Qiagen) according to the manufacturer's instructions. Prior to DNA extraction, separate hematoxylin-eosin stained slides were reviewed by a pathologist. Normal liver tissue was isolated from post-hepatectomy fixed tissue. Tumor tissue was isolated from the initial biopsy at diagnosis and was manually macrodissected. The tumor content was $70 \%$ after macrodissection. DNA and tissue samples were collected by the biobank BB-0033-00024 "Tumorothèque Régionale de Franche-Comté".

\section{Whole exome sequencing}

Library preparation, capture, sequencing, and bioinformatics analysis were performed by IntegraGen, Evry, France. Genomic DNA was captured using SureSelect Human All Exon v4 + UTR - 70 Mb (Agilent) according to manufacturer's instruction and protocols without modification except for library preparation which was performed using NEBNext Ultra kit (New England Biolabs). Pooled capture-enriched DNA samples were then sequenced by paired-end 75 bases massively parallel sequencing on HiSeq 2000 (Illumina).

\section{Bioinformatics analysis}

Base calling was performed using the Real-Time Analysis software sequence pipeline (Illumina, RTA v1.12.4.2) with default parameters. Sequence reads were mapped to the human genome build (hg19/GRCh37) using Elandv2e (Illumina, CASAVA1.8.2) allowing multi-seed and gapped alignments. The duplicated reads were removed. CASAVA1.8.2 was used to call singlenucleotide variants (SNVs) and short insertions/deletions (max. size is $300 \mathrm{nt}$ ), taking into account all reads per position. SNVs and indels with Q (SNPs) $<10$ and $\mathrm{Q}$ (Indel) $<20$, or regions with low mappability (QVCutoff $<90$ ) were filtered out. The frequency with which single base differences were expected between two unrelated haplotypes (Theta parameter) was 0.01 , this frequency was set to 0.001 for indels. Variant annotation took into account data available in dbSNP (dbSNP132), the 1000 Genomes Project (phase1_release_v3.20101123), Hapmap CEU (version27), the Exome Variant Server (ESP6500SI-V2SSA137) and from an in-house database. Genetic variation annotation was realized from IntegraGen in-house pipeline.

In order to identify the germline and somatic variants, we considered that a variant is germline if its frequency is greater than $20 \%$ in normal tissue. Then to ensure only high-confidence transitions calls, we've considered as tumor specific variants only bases with a frequency greater than $5 \%$ in tumor tissue and with a frequency less than $1 \%$ in normal tissue. The tumor specific transitions were selected to identify the mutation signature and we used the stratification by transition contexts into a set of characteristic patterns as described by Alexandrov et al. [27]. This classification of SNVs is based on six base substitutions within tri-nucleotide sequence contexts including the bases immediately at 
$5^{\prime}$ and $3^{\prime}$ of each mutated base. Six base substitutions $(\mathrm{C}>\mathrm{A}, \mathrm{C}>\mathrm{G}, \mathrm{C}>\mathrm{T}, \mathrm{T}>\mathrm{A}, \mathrm{T}>\mathrm{C}$, and $\mathrm{T}>\mathrm{G})$ with 16 possible combinations of neighboring bases result in 96 possible mutation types. The signature obtained was compared to signatures catalogued in the COSMIC database (2017-June).

In order to select neoantigens, others filters were applied. Thus, out of around 50000 variants issued by the variant caller (CASAVA1.8.2), there were 2585 variants from $\mathrm{Hg} 19$ reference in tumor cells including 758 coding variants. Among coding variants, 442 missense variants from hg19 reference in tumor cells, and finally 52 variants were annotated as somatic (ie tumor specific), corresponding to potential neoantigens.

\section{Epitope predictions and peptide libraries}

The MHCII binding predictions were made using the Immune epitope database and binding prediction (IEDB) analysis resource Consensus tool [56, 57] and Syfpeithi [58]. A list of predicted epitopes was obtained and all mutated peptides with a percentile rank $<10$ and/or a binding score $\geq 20$ were synthesized by Proimmune. We also calculated the mean of IC50 values provided by IEDB from SMM align and IC50 from NN align. This value is referred as IC50 in Table 1.

\section{Tandem mini genes (TMG) transfected cell lines}

cDNA encoding 35 amino acids (17 amino acids at each side of the mutation) were selected to design TMG. A TMG is composed of 5 cDNA sequences in tandem in an expression vector (pcDNA3.1). SiHa cell line was stably transfected with TMG (Qiagen Effectene transfection reagent kit 301425) and used to assess the specificity of neopeptide-specific clones.

\section{Assessment of spontaneous antigen-specific $T$ cell response in cancer patients}

Peripheral blood mononuclear cells (PBMC) were isolated by density centrifugation on Ficoll-Hyperpaque gradients (Eurobio) and plated at 2.106 cells per well in a 24-wells plate in RPMI 10\% human serum with the mixture of the four pools of peptides $(2 \mu \mathrm{M})$ as previously described. 50 Recombinant interleukins, IL-7 (5 ng/mL; Peprotech, 200-07) were added at day 1 and IL-2 (20 UI/mL; Novartis) at days 3 and 6. Specific responses were assessed at day 13 by IFN- $\gamma$ ELISPOT (DIACLONE ELISpot kit $856051020 \mathrm{P})$.

Briefly, PBMC (1.105 per well) were cultured on anti-human IFN- $\gamma$ monoclonal antibody- coated ELISPOT plate with each peptide $(2 \mu \mathrm{M})$ in $X$-VIVO 15 medium (Lonza) for $18 \mathrm{~h}$ at $37^{\circ} \mathrm{C}$. Cells cultured with medium alone or PMA (100 ng/mL; Sigma-Aldrich) and ionomycin (10 $\mu \mathrm{mol} / \mathrm{L}$; Sigma-Aldrich) were used as negative and positive controls, respectively. The IFN- $\gamma$ spots were revealed following the manufacturer's instructions. Spotforming cells were counted using the C.T.L. Immunospot system (Cellular Technology Ltd). Responses were considered as positive if spot numbers were superior to 10 and more than twice the number of background spots.

\section{CD4 T-cell clones isolation and amplification}

Specific T-cell clones of mutated peptide 49 were sorted after IFN- $\gamma \mathrm{T}$ cell sorting according to manufacturer's instruction after $6 \mathrm{~h}$ of mutated peptide 49 stimulation (Miltenyi Biotec, 130-054-201). IFN- $\gamma$ secreting $\mathrm{T}$ cells were cloned by limit dilutions and amplified after stimulation by PHA in presence of $35 \mathrm{~Gy}$ irradiated allogeneic PBMCs and $150 \mathrm{UI} / \mathrm{mL}$ of IL-2 according to previously described procedure [59].

\section{Functional assessment of $C D 4+T$ cell clones}

Functional analyses of neoantigens-specific CD4+ T-cell clones were performed by using intracytoplasmic IL-2 and IFN- $\gamma$ staining (ICS). Briefly, after a $14 \mathrm{~h}$ stimulation period with or without $2 \mu \mathrm{M}$, T cells were labeled with fixable viability dye (FVD) (eBioscience, 650865-14), anti-CD3 (BD Biosciences, 558117), anti-CD4 (Diaclone, 954.031.010), anti-IFN- $\gamma$ (BD Biosciences, 554702) using Cytofix/CytoPerm KIT (BD Biosciences, 554714). Stained cells were acquired on a BD FACS Canto II (BD Biosciences) and analyzed with the BD FACS DIVA software. The HLA restriction of the specific TCR was determined with CD4+ $\mathrm{T}$ cell clones treated with $10 \mu \mathrm{g} / \mathrm{mL}$ anti-HLA-DP (B7/21) (Leinco, H260) or anti-HLA-DQ (Bio-rad, MCA3796) or anti-HLA-DR (L243) (BD Biosciences, 555809) antibodies for $30 \mathrm{~min}$ before addition of $2 \mu \mathrm{M}$ of neopeptides for $14 \mathrm{~h}$ before IFN- $\gamma$ ICS. To assess the avidity of T cell clones, 1.105 T cell were culture with 1.105 peptide loaded B-EBV cells (HLA-DRB1 ${ }^{*} 1501$ and HLA-DPB1*0401) for $14 \mathrm{~h}$ before IFN- $\gamma$ ICS.

\section{Processing of neopeptide HELZ2 ${ }^{\mathrm{V} 241 \mathrm{M}}$ (49)}

To study the processing and natural recognition of mutated peptide 49 by $\mathrm{T}$ cell clones, transfected-tumor cell line lysate was loaded on immature MoDC derived from healthy donors. DC were obtained from monocytes cultured for 5 days with $1000 \mathrm{UI} / \mathrm{mL}$ of IL-4 (Peprotech 200-04) and GM-CSF (Peprotech 300-03). Transfected$\mathrm{SiHa}$ cell lysates $(20.106$ cells $/ \mathrm{ml})$ were loaded on immature MoDC for $24 \mathrm{~h}$ at $37^{\circ} \mathrm{C}$. Lipopolysaccharide (LPS; Sigma, L2630) $1 \mu \mathrm{g} / \mathrm{ml}$ was added as a maturation signal for the last $6 \mathrm{~h}$ of culture. After PBS $1 \mathrm{X}$ washing, mature loaded-MoDC were cultured with peptide 49-specific $\mathrm{T}$ cell clones at a $1: 1$ ratio for $18 \mathrm{~h}$ at $37^{\circ} \mathrm{C}$. MoDC loaded with WT or mutated peptide $49(2 \mu \mathrm{M})$ were used as negative and positive control respectively. IFN- $\gamma$ secretion was assessed by ELISA (Diaclone ref 
950.000.192) and acquired on a spectrophotometer (Tecan, XFluor4) according to manufacturer's instructions.

\section{Author contributions}

YG and $\mathrm{CB}$ designed the study. $\mathrm{YG}, \mathrm{CB}$ and $\mathrm{OA}$ coordinated the study. SV, DG, PML, HF, RB and BR performed the experiments and analyzed data. YG, SV, DG, JG and MD were responsible for interpreting results and drafted the manuscript. SK, MJ and CB were in charge of the collection of samples and clinical data collection. All co-authors reviewed the manuscript.

\section{ACKNOWLEDGMENTS}

We would like to acknowledge Antoine Baumann, Inès Saizonou and Dr Sophie Felix from the pathology department of the University Hospital of Besançon for the selection of histology images.

\section{CONFLICTS OF INTEREST}

The authors declare no financial or commercial conflicts of interest.

\section{FUNDING}

Authors are supported by grants from the Conseil Régional de Bourgogne Franche-Comté, the Agence Nationale de la Recherche (Labex LipSTIC, ANR-11LABX-0021).

\section{REFERENCES}

1. Hashim D, Boffetta P, La Vecchia C, Rota M, Bertuccio P, Malvezzi M, Negri E. The global decrease in cancer mortality: trends and disparities. Ann Oncol. 2016; 27:92633. https://doi.org/10.1093/annonc/mdw027.

2. Ursino S, Greco C, Cartei F, Colosimo C, Stefanelli A, Cacopardo B, Berretta M, Fiorica F. Radiotherapy and hepatocellular carcinoma: update and review of the literature. Eur Rev Med Pharmacol Sci. 2012; 16:1599-604.

3. Llovet JM, Brú C, Bruix J. Prognosis of hepatocellular carcinoma: the BCLC staging classification. Semin Liver Dis. 1999; 19:329-38. https://doi.org/10.1055/s-2007-1007122.

4. Llovet JM, Ricci S, Mazzaferro V, Hilgard P, Gane E, Blanc JF, de Oliveira AC, Santoro A, Raoul JL, Forner A, Schwartz M, Porta C, Zeuzem S, et al. Sorafenib in advanced hepatocellular carcinoma. N Engl J Med. 2008; 359:378-90. https://doi.org/10.1056/NEJMoa0708857.

5. Wilhelm S, Carter C, Lynch M, Lowinger T, Dumas J, Smith RA, Schwartz B, Simantov R, Kelley S. Discovery and development of sorafenib: a multikinase inhibitor for treating cancer. Nat Rev Drug Discov. 2006; 5:835-44. https://doi.org/10.1038/nrd2130.

6. Shiba S, Okusaka T, Ikeda M, Saito H, Ichida T. Characteristics of 18 patients with hepatocellular carcinoma who obtained a complete response after treatment with sorafenib. Hepatol Res. 2014; 44:1268-76. https://doi. org/10.1111/hepr.12297.

7. Voron T, Marcheteau E, Pernot S, Colussi O, Tartour E, Taieb J, Terme M. Control of the immune response by proangiogenic factors. Front Oncol. 2014; 4:70. https://doi. org/10.3389/fonc.2014.00070.

8. Keating GM. Sorafenib: A Review in Hepatocellular Carcinoma. Target Oncol. 2017; 12:243-53. https://doi. org/10.1007/s11523-017-0484-7.

9. Kalathil SG, Lugade AA, Miller A, Iyer R, Thanavala Y. $\mathrm{PD}-1+$ and Foxp3+T cell reduction correlates with survival of HCC patients after sorafenib therapy. JCI Insight. 2016; 1:e86182. https://doi.org/10.1172/jci.insight.86182.

10. Cabrera R, Ararat M, Xu Y, Brusko T, Wasserfall C, Atkinson MA, Chang LJ, Liu C, Nelson DR. Immune modulation of effector CD4+ and regulatory $\mathrm{T}$ cell function by sorafenib in patients with hepatocellular carcinoma. Cancer Immunol Immunother. 2013; 62:737-46. https:// doi.org/10.1007/s00262-012-1380-8.

11. Desar IM, Jacobs JH, Hulsbergen-vandeKaa CA, Oyen WJ, Mulders PF, van der Graaf WT, Adema GJ, van Herpen CM, de Vries IJ. Sorafenib reduces the percentage of tumour infiltrating regulatory $\mathrm{T}$ cells in renal cell carcinoma patients. Int J Cancer. 2011; 129:507-12. https://doi. org/10.1002/ijc.25674.

12. Rosmorduc O, Desbois-Mouthon C. Targeting STAT3 in hepatocellular carcinoma: sorafenib again. J Hepatol. 2011; 55:957-9. https://doi.org/10.1016/j.jhep.2011.06.005.

13. Cao M, Cabrera R, Xu Y, Firpi R, Zhu H, Liu C, Nelson DR. Hepatocellular carcinoma cell supernatants increase expansion and function of CD4(+)CD25(+) regulatory $\mathrm{T}$ cells. Lab Invest. 2007; 87:582-90. https://doi.org/10.1038/ labinvest.3700540.

14. Yarchoan M, Xing D, Luan L, Xu H, Sharma RB, Popovic A, Pawlik TM, Kim AK, Zhu Q, Jaffee EM, Taube JM, Anders RA. Characterization of the Immune Microenvironment in Hepatocellular Carcinoma. Clin Cancer Res. 2017; 23:7333-9. https://doi.org/10.1158/10780432.CCR-17-0950.

15. Gao Q, Qiu SJ, Fan J, Zhou J, Wang XY, Xiao YS, Xu Y, Li YW, Tang ZY. Intratumoral balance of regulatory and cytotoxic $\mathrm{T}$ cells is associated with prognosis of hepatocellular carcinoma after resection. J Clin Oncol. 2007; 25:2586-93. https://doi.org/10.1200/JCO.2006.09.4565.

16. Gabrielson A, Wu Y, Wang H, Jiang J, Kallakury B, Gatalica Z, Reddy S, Kleiner D, Fishbein T, Johnson L, Island E, Satoskar R, Banovac F, et al. Intratumoral CD3 and CD8 T-cell Densities Associated with Relapse-Free Survival in HCC. Cancer Immunol Res. 2016; 4:419-30. https://doi. org/10.1158/2326-6066.CIR-15-0110. 
17. Sun L, Xu G, Liao W, Yang H, Xu H, Du S, Zhao H, Lu $\mathrm{X}$, Sang X, Mao Y. Clinicopathologic and prognostic significance of regulatory $\mathrm{T}$ cells in patients with hepatocellular carcinoma: a meta-analysis. Oncotarget. 2017; 8:39658-72. https://doi.org/10.18632/oncotarget.17340.

18. Pardee AD, Butterfield LH. Immunotherapy of hepatocellular carcinoma: Unique challenges and clinical opportunities. Oncoimmunology. 2012; 1:48-55. https://doi. org/10.4161/onci.1.1.18344.

19. Fu J, Zhang Z, Zhou L, Qi Z, Xing S, Lv J, Shi J, Fu B, Liu Z, Zhang JY, Jin L, Zhao Y, Lau GKK, et al. Impairment of $\mathrm{CD} 4+$ cytotoxic $\mathrm{T}$ cells predicts poor survival and high recurrence rates in patients with hepatocellular carcinoma. Hepatology. 2013; 58:139-49. https://doi.org/10.1002/ hep.26054.

20. Unitt E, Rushbrook SM, Marshall A, Davies S, Gibbs P, Morris LS, Coleman N, Alexander GJM. Compromised lymphocytes infiltrate hepatocellular carcinoma: the role of T-regulatory cells. Hepatology. 2005; 41:722-30. https:// doi.org/10.1002/hep.20644.

21. Kreiter S, Vormehr M, van de Roemer N, Diken M, Löwer M, Diekmann J, Boegel S, Schrörs B, Vascotto F, Castle JC, Tadmor AD, Schoenberger SP, Huber C, et al. Mutant MHC class II epitopes drive therapeutic immune responses to cancer. Nature. 2015; 520:692-6. https://doi.org/10.1038/ nature 14426.

22. Tran E, Turcotte S, Gros A, Robbins PF, Lu YC, Dudley ME, Wunderlich JR, Somerville RP, Hogan K, Hinrichs CS, Parkhurst MR, Yang JC, Rosenberg SA. Cancer immunotherapy based on mutation-specific CD4+ T cells in a patient with epithelial cancer. Science. 2014; 344:641-5. https://doi.org/10.1126/science.1251102.

23. Ott PA, Hu Z, Keskin DB, Shukla SA, Sun J, Bozym DJ, Zhang W, Luoma A, Giobbie-Hurder A, Peter L, Chen C, Olive O, Carter TA, et al. An immunogenic personal neoantigen vaccine for patients with melanoma. Nature. 2017; 547:217-21. https://doi.org/10.1038/nature22991.

24. Rai V, Abdo J, Alsuwaidan AN, Agrawal S, Sharma P, Agrawal DK. Cellular and molecular targets for the immunotherapy of hepatocellular carcinoma. Mol Cell Biochem. 2018; 437:13-36. https://doi.org/10.1007/ s11010-017-3092-z.

25. Longo V, Gnoni A, Casadei Gardini A, Pisconti S, Licchetta A, Scartozzi M, Memeo R, Palmieri VO, Aprile G, Santini D, Nardulli P, Silvestris N, Brunetti O. Immunotherapeutic approaches for hepatocellular carcinoma. Oncotarget. 2017; 8:33897-910. https://doi.org/10.18632/oncotarget.15406.

26. Ally A, Balasundaram M, Carlsen R, Chuah E, Clarke A, Dhalla N, Holt RA, Jones SJ, Lee D, Ma Y, Marra MA, Mayo M, Moore RA, et al, and Cancer Genome Atlas Research Network. Comprehensive and Integrative Genomic Characterization of Hepatocellular Carcinoma. Cell. 2017; 169:1327-1341.e23. https://doi.org/10.1016/j. cell.2017.05.046.
27. Alexandrov LB, Nik-Zainal S, Wedge DC, Aparicio SA, Behjati S, Biankin AV, Bignell GR, Bolli N, Borg A, Børresen-Dale AL, Boyault S, Burkhardt B, Butler AP, et al, and Australian Pancreatic Cancer Genome Initiative, and ICGC Breast Cancer Consortium, and ICGC MMML-Seq Consortium, and ICGC PedBrain.

28. Schulze K, Imbeaud S, Letouzé E, Alexandrov LB, Calderaro J, Rebouissou S, Couchy G, Meiller C, Shinde J, Soysouvanh F, Calatayud AL, Pinyol R, Pelletier L, et al. Exome sequencing of hepatocellular carcinomas identifies new mutational signatures and potential therapeutic targets. Nat Genet. 2015; 47:505-11. https://doi.org/10.1038/ ng.3252.

29. Laheurte C, Galaine J, Beziaud L, Dosset M, Kerzerho J, Jacquemard C, Gaugler B, Ferrand C, Dormoy A, Aubin F, Jacoulet P, Westeel V, Borg C, et al. Immunoprevalence and magnitude of HLA-DP4 versus HLA-DR-restricted spontaneous CD4(+) Th1 responses against telomerase in cancer patients. Oncoimmunology. 2016; 5:e1137416. https://doi.org/10.1080/2162402X.2015.1137416.

30. Yarchoan M, Johnson BA, Lutz ER, Laheru DA, Jaffee EM. Targeting neoantigens to augment antitumour immunity. Nat Rev Cancer. 2017; 17:569. https://doi.org/10.1038/ nrc.2017.74.

31. Mizukoshi E, Nakamoto Y, Arai K, Yamashita T, Sakai A, Sakai Y, Kagaya T, Yamashita T, Honda M, Kaneko S. Comparative analysis of various tumor-associated antigenspecific t-cell responses in patients with hepatocellular carcinoma. Hepatology. 2011; 53:1206-16. https://doi. org/10.1002/hep.24149.

32. Flecken T, Schmidt N, Hild S, Gostick E, Drognitz O, Zeiser R, Schemmer P, Bruns H, Eiermann T, Price DA, Blum HE, Neumann-Haefelin C, Thimme R. Immunodominance and functional alterations of tumor-associated antigen-specific CD8+ T-cell responses in hepatocellular carcinoma. Hepatology. 2014; 59:1415-26. https://doi.org/10.1002/ hep.26731.

33. Parsons DW, Li M, Zhang X, Jones S, Leary RJ, Lin JCH, Boca SM, Carter H, Samayoa J, Bettegowda C, Gallia GL, Jallo GI, Binder ZA, et al. The genetic landscape of the childhood cancer medulloblastoma. Science. 2011; 331:435-9. https://doi.org/10.1126/science.1198056.

34. Snyder A, Nathanson T, Funt SA, Ahuja A, Buros Novik J, Hellmann MD, Chang E, Aksoy BA, Al-Ahmadie H, Yusko E, Vignali M, Benzeno S, Boyd M, et al. Contribution of systemic and somatic factors to clinical response and resistance to PD-L1 blockade in urothelial cancer: An exploratory multi-omic analysis. PLoS Med. 2017; 14:e1002309. https://doi.org/10.1371/journal.pmed.1002309.

35. Matsushita H, Vesely MD, Koboldt DC, Rickert CG, Uppaluri R, Magrini VJ, Arthur CD, White JM, Chen YS, Shea LK, Hundal J, Wendl MC, Demeter R, et al. Cancer exome analysis reveals a T-cell-dependent mechanism of cancer immunoediting. Nature. 2012; 482:400-4. https:// doi.org/10.1038/nature10755. 
36. Tran E, Ahmadzadeh M, Lu YC, Gros A, Turcotte S, Robbins PF, Gartner JJ, Zheng Z, Li YF, Ray S, Wunderlich JR, Somerville RP, Rosenberg SA. Immunogenicity of somatic mutations in human gastrointestinal cancers. Science. 2015; 350:1387-90. https://doi.org/10.1126/ science.aad1253.

37. Turcotte S, Gros A, Hogan K, Tran E, Hinrichs CS, Wunderlich JR, Dudley ME, Rosenberg SA. Phenotype and function of $\mathrm{T}$ cells infiltrating visceral metastases from gastrointestinal cancers and melanoma: implications for adoptive cell transfer therapy. J Immunol. 2013; 191:221725. https://doi.org/10.4049/jimmunol.1300538.

38. Salem ME, Xiu J, Lenz HJ, Atkins MB, Philip PA, Hwang JJ, Gatalica Z, Xiao N, Gibney GT, El-Deiry WS, Tan AR, Kim ES, Shields AF, et al. Characterization of tumor mutation load (TML) in solid tumors. J Clin Oncol. 2017; 35:11517-11517. https://doi.org/10.1200/ JCO.2017.35.15_suppl.11517.

39. Jayasinghe RG, Cao S, Gao Q, Wendl MC, Vo NS, Reynolds SM, Zhao Y, Climente-González H, Chai S, Wang F, Varghese R, Huang M, Liang WW, et al, and Cancer Genome Atlas Research Network. Systematic Analysis of Splice-Site-Creating Mutations in Cancer. Cell Reports. 2018; 23:270-281.e3. https://doi.org/10.1016/j. celrep.2018.03.052.

40. Felder M, Kapur A, Gonzalez-Bosquet J, Horibata S, Heintz J, Albrecht R, Fass L, Kaur J, Hu K, Shojaei H, Whelan RJ, Patankar MS. MUC16 (CA125): tumor biomarker to cancer therapy, a work in progress. Mol Cancer. 2014; 13:129. https://doi.org/10.1186/1476-4598-13-129.

41. Balachandran VP, Łuksza M, Zhao JN, Makarov V, Moral JA, Remark R, Herbst B, Askan G, Bhanot U, Senbabaoglu Y, Wells DK, Cary CIO, Grbovic-Huezo O, et al. Identification of unique neoantigen qualities in long-term survivors of pancreatic cancer. Nature. 2017; 551:512-6. https://doi.org/10.1038/nature24462.

42. Stephens PJ, Tarpey PS, Davies H, Van Loo P, Greenman C, Wedge DC, Nik-Zainal S, Martin S, Varela I, Bignell GR, Yates LR, Papaemmanuil E, Beare D, et al. The landscape of cancer genes and mutational processes in breast cancer. Nature. 2012; 486:400-4. https://doi.org/10.1038/ nature11017.

43. Yin S, Yang J, Lin B, Deng W, Zhang Y, Yi X, Shi Y, Tao Y, Cai J, Wu CI, Zhao G, Hurst LD, Zhang J, et al. Exome sequencing identifies frequent mutation of MLL2 in nonsmall cell lung carcinoma from Chinese patients. Sci Rep. 2014; 4:6036. https://doi.org/10.1038/srep06036.

44. Kantidakis T, Saponaro M, Mitter R, Horswell S, Kranz A, Boeing S, Aygün O, Kelly GP, Matthews N, Stewart A, Stewart AF, Svejstrup JQ. Mutation of cancer driver MLL2 results in transcription stress and genome instability. Genes Dev. 2016; 30:408-20. https://doi.org/10.1101/ gad.275453.115.

45. Li CW, Chang PY, Chen BS. Investigating the mechanism of hepatocellular carcinoma progression by constructing genetic and epigenetic networks using NGS data identification and big database mining method. Oncotarget. 2016; 7:79453-73. https://doi.org/10.18632/ oncotarget.13100.

46. Wang XF, Kerzerho J, Adotevi O, Nuyttens H, Badoual C, Munier G, Oudard S, Tu S, Tartour E, Maillère B. Comprehensive analysis of HLADR- and HLA-DP4restricted $\mathrm{CD} 4+\mathrm{T}$ cell response specific for the tumorshared antigen survivin in healthy donors and cancer patients. J Immunol. 2008; 181:431-9.

47. Southwood S, Sidney J, Kondo A, del Guercio MF, Appella E, Hoffman S, Kubo RT, Chesnut RW, Grey HM, Sette A. Several common HLA-DR types share largely overlapping peptide binding repertoires. J Immunol. 1998; 160:3363-73.

48. Kobayashi H, Wood M, Song Y, Appella E, Celis E. Defining promiscuous MHC class II helper T-cell epitopes for the HER2/neu tumor antigen. Cancer Res. 2000; 60:5228-36.

49. Consogno G, Manici S, Facchinetti V, Bachi A, Hammer J, Conti-Fine BM, Rugarli C, Traversari C, Protti MP. Identification of immunodominant regions among promiscuous HLA-DR-restricted CD4+ T-cell epitopes on the tumor antigen MAGE-3. Blood. 2003; 101:1038-44. https://doi.org/10.1182/blood-2002-03-0933.

50. Duan F, Duitama J, Al Seesi S, Ayres CM, Corcelli SA, Pawashe AP, Blanchard T, McMahon D, Sidney J, Sette A, Baker BM, Mandoiu II, Srivastava PK. Genomic and bioinformatic profiling of mutational neoepitopes reveals new rules to predict anticancer immunogenicity. J Exp Med. 2014; 211:2231-48. https://doi.org/10.1084/jem.20141308.

51. Bobisse S, Genolet R, Roberti A, Tanyi JL, Racle J, Stevenson BJ, Iseli C, Michel A, Le Bitoux MA, Guillaume P, Schmidt J, Bianchi V, Dangaj D, et al. Sensitive and frequent identification of high avidity neo-epitope specific CD8 + T cells in immunotherapy-naive ovarian cancer. Nat Commun. 2018; 9:1092. https://doi.org/10.1038/s41467-018-03301-0.

52. Yewdell JW, Bennink JR. Immunodominance in major histocompatibility complex class I-restricted T lymphocyte responses. Annu Rev Immunol. 1999; 17:51-88. https://doi. org/10.1146/annurev.immunol.17.1.51.

53. Mennonna D, Maccalli C, Romano MC, Garavaglia C, Capocefalo F, Bordoni R, Severgnini M, De Bellis G, Sidney J, Sette A, Gori A, Longhi R, Braga M, et al. T cell neoepitope discovery in colorectal cancer by high throughput profiling of somatic mutations in expressed genes. Gut. 2017; 66:454-63. https://doi.org/10.1136/gutjnl-2015-309453.

54. El-Khoueiry AB, Melero I, Crocenzi TS, Welling TH, Yau TC, Yeo W, Chopra A, Grosso J, Lang L, Anderson J, Dela Cruz CM, Sangro B. Phase I/II safety and antitumor activity of nivolumab in patients with advanced hepatocellular carcinoma (HCC): CA209-040. J Clin Oncol. 2015; 33:LBA101. https://doi.org/10.1200/jco.2015.33.18_suppl. lba101. 
55. Zhou G, Sprengers D, Boor PPC, Doukas M, Schutz H, Mancham S, Pedroza-Gonzalez A, Polak WG, de Jonge J, Gaspersz M, Dong H, Thielemans K, Pan Q, et al. Antibodies Against Immune Checkpoint Molecules Restore Functions of Tumor-Infiltrating T Cells in Hepatocellular Carcinomas. Gastroenterology. 2017; 153:1107-1119.e10. https://doi. org/10.1053/j.gastro.2017.06.017.

56. Wang P, Sidney J, Dow C, Mothé B, Sette A, Peters B. A systematic assessment of MHC class II peptide binding predictions and evaluation of a consensus approach. PLoS Comput Biol. 2008; 4:e1000048. https://doi.org/10.1371/ journal.pcbi.1000048.

57. Wang P, Sidney J, Kim Y, Sette A, Lund O, Nielsen M, Peters B. Peptide binding predictions for HLA DR, DP and
DQ molecules. BMC Bioinformatics. 2010; 11:568. https:// doi.org/10.1186/1471-2105-11-568.

58. Rammensee H, Bachmann J, Emmerich NP, Bachor OA, Stevanović S. SYFPEITHI: database for MHC ligands and peptide motifs. Immunogenetics. 1999; 50:213-9.

59. Godet Y, Fabre E, Dosset M, Lamuraglia M, Levionnois E, Ravel P, Benhamouda N, Cazes A, Le Pimpec-Barthes F, Gaugler B, Langlade-Demoyen P, Pivot X, Saas P, et al. Analysis of spontaneous tumor-specific CD4 T-cell immunity in lung cancer using promiscuous HLA-DR telomerase-derived epitopes: potential synergistic effect with chemotherapy response. Clin Cancer Res. 2012; 18:294353. https://doi.org/10.1158/1078-0432.CCR-11-3185. 